\title{
SIMS study of deuterium distribution and thermal stability in ZMR SOI structures
}

\author{
A. Boutry-Forveille and D. Ballutaud \\ LPSB-CNRS, Solid State Physics Laboratory, Bellevue, France
}

\section{A. N. Nazarov}

Institute of Semiconductor Physics, NAS Ukraine, 45 prospekt Nauki, Kyiv, 252028, Ukraine

\begin{abstract}
SIMS measurements and thermal effusion experiments were performed to study the distribution and thermal stability of deuterium in SOI structures fabricated by zone melting recrystallization technique. It was found that the disordered structure at the silicon-buried oxide interfaces is directly related to the distribution of deuterium in the SOI system. The diffusion coefficient of deuterium in the top silicon layer at $250^{\circ} \mathrm{C}$ was determined. For the first time, the high-temperature (up to $600^{\circ} \mathrm{C}$ ) stability of deuterium in the buried oxide was demonstrated, without any diffision into silicon layers.
\end{abstract}

Keywords: silicon-on-insulator, deuterium, SIMS, thermal effusion.

Paper received 19.08.98; revised manuscript received 19.10.98; accepted for publication 28.10.98.

\section{Introduction}

The important role of hydrogen in a variety of technological processes employed for fabrication of semiconductor devices is well known. RF plasma hydrogenation leads to a considerable decrease in the concentration of electrically active traps in polycrystalline Si films [1], and hydrogen annealing of $\mathrm{Si}_{-} \mathrm{SiO}_{2}$-structures is a widely used technique for production of structures with a low interface state density [2]. Some processes resulting in thermal instability and the radiation-induced increase in the density of interface states in metal- $\mathrm{SiO}_{2}$-Si structures are associated with fast diffusing particles, including hydrogen atoms [3-5]. In addition, hydrogen has the excellent ability to be trapped at the reactive sites in silicon [6] and in dielectric layers, such as $\mathrm{SiO}_{2}$ [7]. Therefore, its distribution should be related to the quality of semiconductor and dielectric layers.

Thus, studies of hydrogen trapping and redistribution during thermal annealing in semiconductors and insulators are important for elucidating the reasons for electric charge instabilities in multilayer structures containing dielectric films.

The silicon-on-insulator (SOI) structure is very promising for high-speed, interference-immune, and high-tempera- ture integrated circuits (IC's) [8]. In this paper, we study hydrogen distribution and thermal stability in SOI structures fabricated by the laser zone-melting recrystallization (ZMR) technique, which is very attractive for production of lowcost SOI wafers with thin $(150-400 \mathrm{~nm})$ silicon layers having charge carrier mobilities close to those in single-crystal silicon.

\section{Samples and experimental technique}

SOI structures with the thickness of silicon and silicon dioxide films equal to 450 and $350 \mathrm{~nm}$, respectively, were fabricated by the laser ZMR technique [9]. The dioxide layer was grown by high-pressure thermal oxidation of the silicon substrate. The top silicon layer consists of slightly misoriented single-crystalline grains separated by subboundaries. The average distance between the subboundaries is about $200 \mathrm{~nm}$ (as can be seen from fig. 2 in Ref. 9).

Samples were deuterated in a diode RF plasma reactor. The deuterium concentration profiles were obtained by SIMS measurements with CAMECA IMS4F system. The primary ion was $14 \mathrm{keV} \mathrm{Cs}^{+}$, with the ion current of $5 \times 10^{-3} \mathrm{~A} / \mathrm{cm}^{2}$. 


\section{A. Boutry-Forveille et al.: SIMS study of deuterium distribution...}
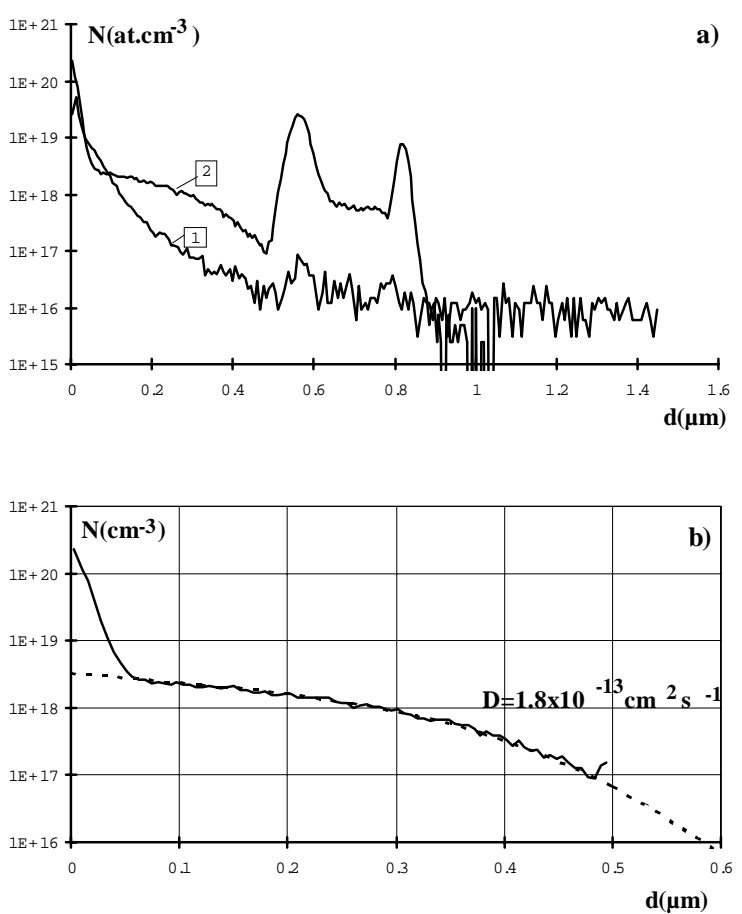

Fig. 1. (a) Deuterium distribution in a ZMR SOI structure after deuteration for $30 \mathrm{~min}\left(1 \mathrm{~W} / \mathrm{cm}^{2}\right)$ at the following temperatures: $1-150^{\circ} \mathrm{C} ; 2-250^{\circ} \mathrm{C}$. (b) Deuterium distribution in a recrystallized silicon film deuterated at $250^{\circ} \mathrm{C}$ for $30 \mathrm{~min}$ at $1 \mathrm{~W} / \mathrm{cm}^{2}($ experimental result; - - - - calculated for $\left.\mathrm{D}=1.8 \times 10^{-13} \mathrm{~cm}^{2} \mathrm{~s}^{-1}\right)$.

The absolute values of concentration were determined by calibration with respect to a deuterium-implanted reference sample. The crater depths were measured with a Tencortype profilometer. Although the absolute values of deuterium concentrations in the oxide layer were unknown, the concentrations of deuterium in different samples can be compared. The deuterated samples were annealed in an evacuated quartz tube $\left(10^{-10}\right.$ mbar $)$.

In addition, thermal deuterium effusion measuremenst [10] were performed with a quadrupole mass spectrometer connected to an evacuated quartz tube $\left(10^{-10} \mathrm{mbar}\right)$ with the deuterated sample subjected to linear heating at the rate of $0.25 \mathrm{~K} / \mathrm{sec}$. The temperature of measurements ranged from the room temperature up to $1000^{\circ} \mathrm{C}$.

\section{Results and discussion}

Figure 1a shows the effect of deuteration temperature on the distribution of deuterium in the ZMR SOI structure. As can be seen, the RF plasma treatment at $250^{\circ} \mathrm{C}$ results in deuterium penetration through the silicon layer and its uptake in the buried oxide (BOX). Two intensive deuteruim peaks corresponding to the top silicon layer-BOX and substrateBOX interfaces are observed from SIMS. No deuterium penetration into the silicon substrate through the $\mathrm{BOX}$ is
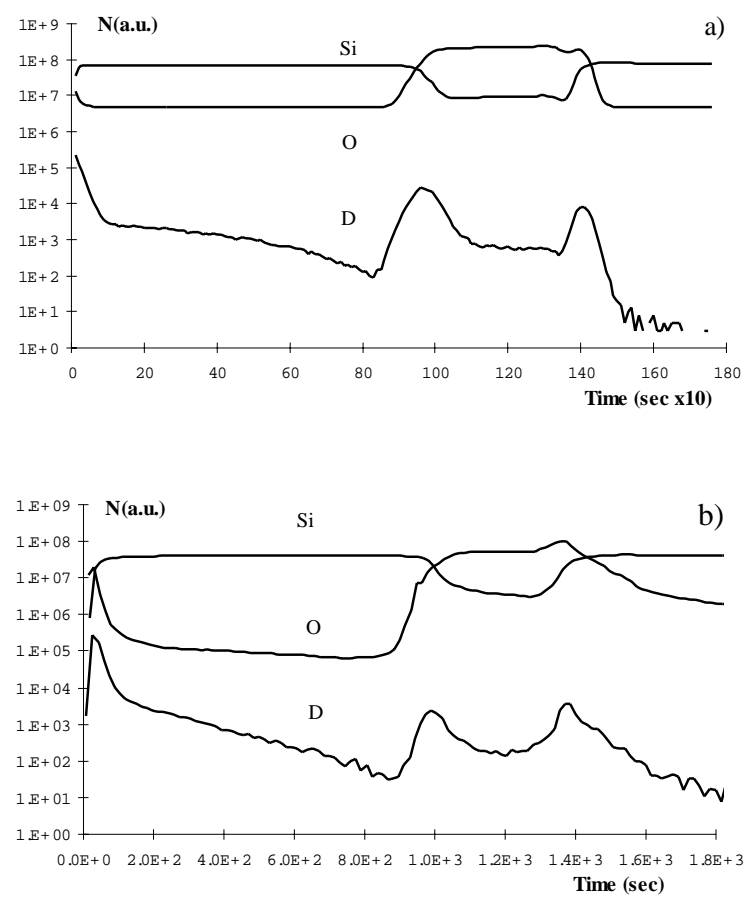

Fig. 2. SIMS profiles for $\mathrm{Si}, \mathrm{O}$, and $\mathrm{D}$ in a ZMR SOI structure before (a) and after (b) thermal annealing up to $1200^{\circ} \mathrm{C}$.

observed at the measurement temperatures used. On the other hand, the deuterium diffusion profile does not depend on the RF plasma power over the range of experimental parameters studied.

The diffusion profile of deuterium in the top silicon layer obeys the erfc function behaviour (see fig. 1(b)) with a coefficient of $1.8 \times 10^{-13} \mathrm{~cm}^{2} \mathrm{~s}^{-1}$ at $250^{\circ} \mathrm{C}$, which corresponds to the trap-limited diffusion in poly-silicon [11]. Indeed, the laser-recrystallized silicon film consists of a large number of single-crystalline grains. It is probable that the enhanced diffusion of deuterium through the grain boundaries in the silicon film occurs.

The existence of two wide deuterium peaks corresponding to the BOX-silicon interfaces suggests the presence of quite thick transition layers and of a great number of strained and dangling bonds at these interfaces. The correlation between the width of the deuterium peak and the thickness of the transition layer can be demonstrated by the results presented in fig. 2. Fig. 2(a) shows the deuterium diffusion profile along with silicon and oxygen profiles for a ZMR SOI structure deuterated at $250^{\circ} \mathrm{C}$ for 30 minutes. The width of oxygen and of silicon distributions in the transition layers of the BOX-top silicon and the BOX-substrate interface is directly related to the halfwidth of deiterium peaks for these interfaces. For an SOI structure annealed at the temperature up to $1200^{\circ} \mathrm{C}$ before the deuteration, the redistribution of silicon and oxygen profiles observed after this treatment is accompanied by expansion of the deuterium peak (fig. 2(b)). This is particularly pronounced for the BOX-substrate interface. 


\section{A. Boutry-Forveille et al.: SIMS study of deuterium distribution...}

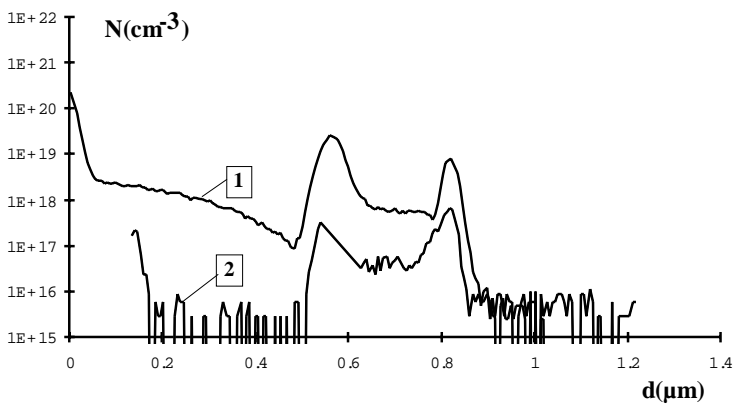

Fig. 3. Deuterium distribution in a ZMR SOI structure after deuteration at $250^{\circ} \mathrm{C}, 1 \mathrm{~W} / \mathrm{cm}^{2}$ for $30 \mathrm{~min}$ (1) and after thermal annealing of the deuterated sample at $600^{\circ} \mathrm{C}$ for 2 hours (2).

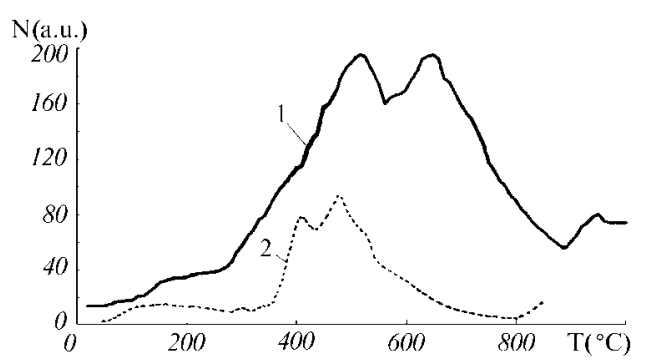

Fig. 4. Deuterium effusion spectra of deuterated ZMR SOI structure (1) and poly-Si sample (2) (from ref. [11]).

The wider deuterium peak for the BOX-top silicon interface in comparison to the BOX-substrate interface can be attributed to a more disordered transition layer at the former interface. In addition, this interface can display some waviness with the amplitude of about $20 \mathrm{~nm}$ [8].

In the entire temperature range studied, the distribution of deuterium preserves two peaks located at the BOX-silicon interfaces. This result is considerably different from that for SOI structures manufactured by separation using the implanted oxygen (SIMOX) technique. After a high-temperature annealing at $500^{\circ} \mathrm{C}$, the deuterium in the BOX usually has a flat distribution related to a significant concentration of broken and strained bonds in the BOX [12]. So, for a ZMR SOI system, the structure of the amorphous network in the BOX is probably better than for a SIMOX system.

Thermal annealing of the deuterated ZMR SOI structures in vacuum shows that $\mathrm{BOX}$ can contain deuterium at temperatures higher than $600^{\circ} \mathrm{C}$, retaining the deuterium profile in the BOX with two peaks (fig. 3). It is worth noting that, after thermal annealing at $600^{\circ} \mathrm{C}$ for 2 hours, deuterium effuses from the top silicon layer, and SIMS measurements do not detect any presence of deuterium in the recrystallized silicon film.

Thermal effusion experiments performed on SOI structures show the following four deuterium effusion ranges: from 20 to $250^{\circ} \mathrm{C}$; a thermal effusion peak with the maximum at $500^{\circ} \mathrm{C}$; a thermal effusion peak with the maximum at $670^{\circ} \mathrm{C}$, and a rise of deuterium effusion from 900 to $1000^{\circ} \mathrm{C}$ (fig. 4). Comparison of this spectrum to that of deuteruim thermal effusion from a thick polysilicon layer, which is also shown in fig. 4 [11], allows us to conclude that the thermal effusion peak with the maximum at $670^{\circ} \mathrm{C}$ is probably related to deuterium effusion from the BOX.

It is worth noting that deuterium incorporated into the BOX of a SOI structure can be contained there at sufficiently high temperatures without diffusion into the silicon layer. Therefore, we have for the first time directly observed the blocking properties of the BOX-silicon interface for deuterium at high temperatures.

\section{Conclusions}

Over the range of experimental parameters used in this study, deuterium does not diffuse through the thermal oxide into the silicon substrate.

Intense deuterium peaks corresponding to the BOX-silicon interfaces indicate a significant trapping of deuterium between the thermal BOX and the silicon layer.

For the first time, the blocking properties of the BOXsilicon interface at high temperatures were directly demonstrated. Deuterium contained in the BOX is stable and can still be detected there after thermal annealing at $600^{\circ} \mathrm{C}$ for 2 hours.

\section{Acknowledgements}

The authors would like to thank Professor E. I. Givargizov and Dr. A. B. Limanov (Institute of Crystallography RAS, Moscow, Russia) for useful discussions and for the samples provided.

This work was performed in the framework of CNRS project N5736. One of the authors (A.N.N.) appreciates partial financial support provided by CRDF (CRDF project UP2291).

\section{References}

1. M. Aucouturier, Physica B, 170, 469 (1991)

2. K. L. Brower, Phys. Rev. B, 38, 9657 (1988)

3. C. R. Helms and J. D. Plummer, Rep. Prog. Phys., 57, 791 (1994)

4. K. Vanheusden, R. A. B. Devine, J. R. Schwank, D. M. Fleetwood, R. G. Polcawich, W. L. Warren, S. P. Karnaand R. D. Pugh, IEEE Tr. Nucl. Sci., 44, 2087 (1997)

5. B. J. Mrstik and R. W. Rendell, IEEE Tr. Nucl. Sci., 38, 1101 (1991)

6. S. Acco, W. Beyer, E. E. van Faassen and W. F. van der Weg, J. Appl. Phys., 82, 2862 (1997)

7. S. M. Myers and P. M. Richards, J. Appl. Phys., 67, 4064 (1990)

8. J.-P. Colinge, Silicon-On-Insulator technology: materials to VLSI, Kluwer, Norwell (1991)

9. E. I. Givargizov, V. A. Loukin and A. B. Limanov, in Physical and technical problems of SOI structures and devices, NATO ASI Series 3/4, ed. by J.-P. Colinge, V. S. Lysenko and A. N. Nazarov, pp. 27-38. Kluwer, Dordrecht (1995)

10. M. Stutzmann and M. S. Brand, J. Appl. Phys., 68, 1406 (1990)

11. L. Lusson, P. Elkaim, A. Correia and D. Ballutaud, J. Phys. III (France), 5, 1173 (1995)

12. S. M. Myers, G. A. Brown, A. G. Revesz and H. L. Hughes, J. Appl. Phys., 73, 2196 (1993) 


\section{SIMS ДОСЛІДЖЕННЯ РОЗПОДІЛУ ДЕЙТЕРІЯ I ТЕМПЕРАТУРНОЇ СТАБІЛЬНОСТI В ZMR SOI} СТРУКТУРАХ

А. Боутрі-Форвейле, Д. Баллутауд

ЛПСБ-ЦНРС, лабораторія фізики твердого тіла, Франція

О. М. Назаров

Інститут фізики напівпровідників НАН Украӥни

У роботі вивчались методами вторинної іонної мас-спектрометрії (BIMC) і термостимульованої десорбції дейтерію розподілення дейтерію і його термічна стабільність у системі кремній-на-ізоляторі (КНІ), виготовленій за допомогою технології зонної лазерної рекристалізації полікремнію. Показано існування прямого зв’язку між розупорядкуванням структури на межах розподілу кремнійвнутрішній діелектрик і розподіленням дейтерію у системі КНІ. Визначено коефіцієнт дифузії дейтерію у кремнієвій рекристалізованій плівці при $250^{\circ} \mathrm{C}$. Вперше продемонстровано високотемпературну стабільність дейтерію (до $600^{\circ} \mathrm{C}$ включно) у внутрішньому діелектрику системи КНІ, за відсутності дифузії дейтерію до кремнієвих шарів.

\section{SIMS ИССЛЕДОВАНИЯ РАСПРЕДЕЛЕНИЯ ДЕЙТЕРИЯ И ТЕМПЕРАТУРНАЯ СТАБИЛЬНОСТЬ В ZМR SOI СТРУКТУРАХ}

А. Боутри-Форвейле, Д. Баллутауд

ЛПСБ-ЦНРС, лаборатория физики твердого тела, Франция

\section{О. М. Назаров}

Институт физики полупроводнков НАН Украины

В работе методами вторичной ионной масс-спектрометрии (ВИМС) и термостимулированной десорбции дейтерия изучались распределение дейтерия и его термическая стабильность в структурах кремния-на-изоляторе (КНИ), изготовленных с помощью технологии зонной лазерной рекристаллизации поликремния. Показано существование прямой связи между разупорядочением структуры на границах кремний-внутренний окисел и распределением дейтерия в КНИ системе. Определен коэффициент диффузии дейтерия в рекристаллизованном слое кремния при $250^{\circ} \mathrm{C}$. Впервые продемонстрирована высокотемпературная стабильность дейтерия (до $600^{\circ} \mathrm{C}$ включительно) во внутреннем окисле КНИ структуры при отсутствии диффузии дейтерия в кремниевые слои. 